\title{
Micro-neoliberalism in China: Public-Private Interactions at the Confluence of Mainstream and Shadow Education
}

\author{
Corresponding author: ZHANG Wei
}

Affiliation: The University of Hong Kong

Address: Comparative Education Research Centre, Faculty of Education, The University of Hong Kong, Pokfulam Road, Hong Kong

Email: weizh@hku.hk

\section{Second author: Mark BRAY}

Affiliation: The University of Hong Kong

Address: Comparative Education Research Centre, Faculty of Education, The University of Hong Kong, Pokfulam Road, Hong Kong

Email: mbray@hku.hk

\begin{abstract}
With its shift to a market economy gathering speed from the 1990s, the Chinese government embarked on an agenda that brought neoliberal forces into almost all sectors including education. The policies underpinned China's spectacular economic growth, but in education have had consequences that arguably are problematic.

Drawing on a mixed-methods study in Shanghai, this paper examines 'micro-neoliberalism' in China's education system, i.e. privatization and marketization at the individual, family and institutional levels, with focus on blurring boundaries between public schooling and private supplementary tutoring. Some dimensions of these processes resulted from deliberate macro-level policies to decentralize control of schooling, raise performance, and empower private education. Other dimensions arose from the market behavior of individuals, families and institutions that countered government efforts to steer parental choice of schools and to reduce disparities between schools. Education policies are enacted not only in schools but also in the shadow sector which is commonly overlooked. This paper focuses on Shanghai but has implications for other parts of China; and since shadow education is expanding as a global phenomenon, it also has relevance to many other countries.
\end{abstract}

Keywords: China; micro-neoliberalism; private supplementary tutoring; shadow education; Shanghai 


\section{Introduction}

China has undergone dramatic change during the last three decades. Under the strong communist ideology that prevailed from 1949 until the 1970s, private enterprise was strictly prohibited. This ideology loosened by stages, and from the 1990s new policies brought increasingly visible privatization and marketization (Coase \& Wang 2012; Wu 1999), including in the education sector (Guo et al. 2013; Koo 2016). This paper is partly concerned with mainstream government-provided schooling and partly with the so-called shadow education sector of private supplementary tutoring. The literature uses the shadow metaphor because in content the sector to a large extent copies the mainstream - as the mainstream curriculum changes, so does the shadow curriculum; and as the mainstream expands or contracts, so does the shadow (Aurini, Davies \& Dierkes 2013; Bray 1999; Bray \& Lykins 2012; Jokić 2013). The paper is concerned with both primary and secondary education, and with fee-charging services alongside fee-free schooling.

In China, shadow education greatly expanded as the society became more prosperous and competitive (Shen 2008; W. Zhang \& Bray 2015). It has attracted increasing public concern because it exacerbates social inequalities and imposes academic burdens on students, but has not been given adequate attention by either the government or researchers, chiefly because of the traditions of equating education with schooling. This paper points out that shadow education is part of wider processes of overt and covert privatization, and has far-reaching implications for the enactment of educational policies.

Much literature has shed light on how macro-level neoliberal forces may generate destructive forms of competition, exacerbate social, economic, and spatial inequalities, and undermine the quality of schooling (Apple 2006; Ball 2006; Lipman 2011; Olssen \& Peters 2005; Peck \& Tickell, 2002; Ward 2013). Parts of this literature argue that education markets have reduced teaching and learning to performativity, and that professionalism and ethical commitments have been devalued in the face of market principles and institutional survival. Ball $(2006,143)$ suggested that "the epidemic of [neoliberal] reform does not simply change what we, as educators, scholars and researchers do, it changes who we are”. The present paper is concerned with what the authors call micro-neoliberalism, i.e. forces and responses at the level of individuals, families and institutions.

China's move to the market economy has been fueled by a mix of deliberate macro-neoliberal policies and independent forces released by the relaxation of authoritarian centralized control (Coase \& Wang 2012; Guo \& Guo 2016). As neoliberal elements have permeated the society and values have been adjusted, forces which were previously marginal or absent have taken hold and developed entirely new sectors. Shadow education is among these sectors. It has not emerged as a result of top-down planning; rather it has been driven by the actions of school leaders, teachers, entrepreneurs, parents and students.

This paper investigates how the various actors operate at the confluence of mainstream and shadow education. It asks what the patterns imply for government efforts to lessen the study burden on students and to promote education equality. Data are presented from Shanghai, but the overall themes have much wider relevance. The paper identifies dynamic forces that add to conceptual understanding of both neoliberalism and relationships between mainstream schooling and shadow education. The 
analysis includes focus on ways in which government efforts to equalize educational provision have been subverted by the shadow sector.

\section{Global Patterns and Implications of Shadow Education}

Shadow education has long been a significant phenomenon in East Asia (see e.g. Sato 2012; Seth 2002; Zeng 1999). Patterns in Korea are particularly notable: $56.2 \%$ of general high school students, $69.1 \%$ of middle school students, and $81.1 \%$ of elementary school students received private supplementary tutoring in 2014 (Korean Statistical Information Service 2015). Some tutoring was provided by university students and other individuals, but most was provided through institutions called hagwons. Japanese juku are also well known, and according to Ministry of Education data (Japan 2015, 66) in 2015 47.7\% of Primary 6 and 60.8\% of Grade 9 students received tutoring in juku or with individual tutors. Related statistics from Hong Kong indicated that in 2011/12, 81.8\% of Grade 12 students and 53.8\% of Grade 9 students were receiving shadow education (Bray 2013, 20).

Shadow education also has a long history and significant scale in other regions. Kassotakis and Verdis (2013, 94) sketched expansion of the phenomenon in Greece during the $20^{\text {th }}$ century, and indicated (p.99) that in 2010/11 nearly 60\% of secondary students attended tutoring institutions known as frontistiria. In Egypt, a 1990/91 survey of students in Grades 5 and 8 found that 65\% of urban students and 53\% of rural ones were receiving private tutoring (Fergany 1994, 75); and a decade and a half later a 2005 report (cited by Hartmann 2013, 60) indicated that 64\% of urban families and 54\% of rural families paid for private tutoring. In England, 25\% of respondents to a 2015 survey asking whether they had ever received private or home tutoring replied affirmatively, and in London the proportion was 44\% (Sutton Trust 2015). Comparable numbers, of course with variations, may be found elsewhere. Shadow education is already strong in many countries and is expanding globally in both prosperous and low-income societies (Aurini, Davies \& Dierkes 2013; Bray 2009; Bray \& Lykins 2012).

The question then is about the implications of this phenomenon. On the positive side, shadow education is likely to increase students' learning, which in turn can contribute to social and economic development. It provides employment for tutors, and it can provide a constructive environment for children and youths who would otherwise lack such an environment (Manzon \& Areepattamannil 2014). At the lower end of the age range, tutoring may perform a child-minding function for working parents who are not available to collect their children from schools with short days; and at the higher end, tutoring may be viewed by parents as worthwhile for teenagers who might otherwise be engaged in less desirable activities (see e.g. Tan 2009).

Yet shadow education also has a negative side. Social inequalities derive from the facts that rich households can afford more and better quality shadow education than can poor households, and that these investments translate into educational achievements and subsequent lifelong earnings (see e.g. Bray 1999; Jo 2013; Jokić 2013). Another challenge, prominent among discussions in Shanghai, concerns the burden on students who have heavy schedules of supplementary lessons on top of their 
standard school days. Psychologists and others are wary of demands on students who have inadequate time for sports and play (see e.g. Choi \& Cho 2015).

A further set of challenges concerns the backwash on schools. Long hours of evening study may make students tired in the daytime; and students who are choosing and paying their tutors may respect them more than their teachers who imposed on them and are free of charge. Sometimes the curriculum in the shadow is inconsistent with the curriculum in the schools, and thus causes confusion; and some tutors cover the content ahead of the schools, increasing the likelihood that students will be bored in their regular classes. Further when teachers are also tutors they may reserve their energies for the private lessons, knowing that they will receive their standard salaries provided their school-based work is not seriously problematic (see e.g. Bray et al. 2016; Kobakhidze 2014; Hartmann 2013). These situations arise in almost all countries, including China, and create a need for what Kodakos and Kalavasis (2015) have called "border management models". Border management is especially necessary when teachers privately tutor their own students, since dangers arise of favoritism for the students receiving tutoring and of deliberate withholding of content during regular lessons in order to promote demand during the private classes.

Because shadow education may have negative implications, some observers recall eras in which private tutoring was uncommon and view the expansion of the shadow sector as a pollutant in an environment that had been relatively clean. This view should be balanced by the more positive views of tutoring as a beneficial activity; but the notion is introduced here because it is pertinent to the mixing zones that the paper will consider at the confluence of mainstream and shadow education.

\section{The Specific Research Site}

Peck, Theodore and Brenner (2009) note that neoliberalism is a strong self-reinforcing discourse, and advocate a subtle spatial analysis of neoliberalization processes with considerable regional differences in regulatory arrangements. This perspective emphasizes the context-embeddedness of "actually existing neoliberalism" (p.53) and recognizes cities as "strategic targets and proving grounds for an increasingly broad range of neoliberal policy experiments, institutional innovations and political projects" (p.65). The analysis of micro-neoliberalism in the present paper is situated in the city that is arguably the leading incubator for China's neoliberal project.

This paper draws on data from Shanghai - China's international economic, financial, trading and shipping center (Shanghai Municipal People's Government 2015). With a population of 24.2 million, Shanghai is the second largest city in China after Chongqing. Within Shanghai's population, 14.2 million are classified as permanent residents and 9.9 million are described as floating population, without registered residence (hukou) in Shanghai (SMBS 2014). In 2013, Shanghai had a per capita Gross Domestic Product of US\$14,645 (SMBS 2014), and thus considerable wealth for household investment in education and other domains. The figure contrasted with US\$6,812 for China as a whole (National Bureau of Statistics of China 2014). Shanghai is also among the Chinese cities most exposed to neoliberal forces in all sectors (Ding 2011). Shanghai is thus different from other Chinese cities in significant respects. 
However, many of the forces identified in this paper are also applicable elsewhere in the country (see e.g. Guo et al. 2013; W. Zhang \& Bray 2016); and insofar as Shanghai is different, to some extent that is because it is leading the way on a path that others will follow. Shanghai served as an experimental field for the system of nine years of compulsory education that has now become national policy, and was the first city to achieve universal primary and secondary schooling (Shanghai Education Commission [SEC] 2012). Shanghai is also well known for leadership in the Programme for International Student Assessment (PISA) sponsored by the Organisation for Economic Co-operation and Development (OECD) (Sellar \& Lingard 2013; Tan 2013; M. Zhang et al. 2011) with lessons now being followed by other provinces.

Yet while Shanghai is at the forefront of change, some cultural traditions remain strong (Cheng 2010; M. Zhang \& Kong 2012). For example, parents hold strong belief in success through diligence, and have high expectations of their children's education. Further, this paper will make extensive reference to examinations that have an ancestry in the Imperial Examination System for personnel selection and that have long been perceived as a mechanism for upward mobility of lower-class families.

Shanghai's school system comprises five years of primary, four years of lower secondary, and three years of upper secondary schooling in the academic track (SEC 2012). Most schools are run by district authorities with local finance, which creates disparities in the quality of schools among the urban, suburban, peripheral and rural areas. Alongside these district-managed schools are six demonstration upper secondary schools run by the municipal government (SEC 2013a). The authorities have endeavored to reduce disparities, but still classify upper secondary schools as experimental demonstration schools or ordinary schools according to their infrastructure and educational quality. The elite schools were formerly called key schools. Now this label has been removed officially, but it remains in common parlance and perception.

Although Shanghai surprised both itself and the international community by showing the highest achievements in many components of the 2009 PISA test, dissatisfaction with the education system remains among the various levels of government and among families, students and educators. The authorities welcome the human capital produced through tutoring which helps to increase economic competitiveness, but worry about the pressures on young people and about social disparities (Cheng 2010; China 2010; W. Zhang 2014). In an arena with cross-cutting forces, the authorities find that enactment of education policies is not simple. Likewise families feel stressed by social competition, and to some extent face a 'prisoner's dilemma' (Yu \& Ding 2011). They are keenly aware of pressures on their children, and many would like to avoid shadow education but do not dare to do so. Teachers are similarly ambivalent, on the one hand desiring whole-person development but on the other hand recognizing the pressures of academic achievement in the competitive arena.

\section{The Data}

The study from which the data for this paper were drawn employed mixed methods to secure the strengths of both quantitative and qualitative components (Johnson \& Christensen 2012). 
Questionnaires were used to survey Grades 3-9 students in May 2014, and interviews were conducted in June 2015 to obtain qualitative information from students, parents, school practitioners and tutoring providers. Most findings presented here are from the qualitative data, but they are supplemented by quantitative components.

The survey used three-stage stratified sampling. Shanghai was first divided into the urban, suburban and peripheral areas, and one district was then randomly selected from each area. Next, in each sampled urban area (District A) and suburb (District B), two primary schools and two lower secondary schools were randomly selected. In the periphery (District C), four primary and four lower secondary schools were selected randomly. A larger sample was secured in District C since the numbers of schools and students were significantly greater than in the other two locations. Within the target grades of each sampled school, 30 students were randomly selected. Thus, data were solicited from 1,680 students in eight primary schools and eight lower secondary schools in three districts. Usable responses were obtained from 1,531 students.

The survey questionnaire was adapted from an instrument developed for Hong Kong and Chongqing and employed in other countries (Liu 2015). The survey was conducted on-line. Students with the facilities to respond online from home were given a slip with log-on information and instructed by their teachers how to complete the survey. Some schools organized the sampled students to complete the survey on the school premises. The survey data were then analyzed with the Statistical Package for the Social Sciences (SPSS).

The interviewees were selected through a combination of purposeful and opportunistic sampling. The researchers first employed the principle of maximal variation sampling to identify the institutions (Creswell 2012, 208). Thirty schools were invited to participate, among which 12 accepted. They comprised two elite primary schools (one private and one public), three ordinary primary schools (all public), three elite lower secondary schools (one public and two private), two ordinary lower secondary schools (both public), and two elite upper secondary schools (both public).

Within the schools, teachers and students for interview were identified in conjunction with the school authorities according to availability. The researchers sought balances between males and females, and between students with and without tutoring. However, the sample was constrained by the circumstances of each sampled school and willingness to participate. A government official, parents and tutors were recruited through opportunistic sampling (Patton 2002, 244). Most interviews were semi-structured while a few with parents and tutors were informal (Spradley 1979; Bernard \& Ryan 2010) according to judgments made by the researchers in specific circumstances. Interviews were mainly conducted in classrooms of schools and tutoring centers, with each lasting for 40 minutes to an hour. Views were collected on reasons for tutoring, forms of tutoring, and the relationships between tutoring and schooling, parenting and the larger society. Interview data were obtained from 43 students, 31 teachers, five principals, seven parents, a government official, two tutors, and the manager of a tutoring enterprise. Thematic coding (Gibbs 2007) was used to analyze the transcripts.

\section{Macro-Neoliberal Changes in China's Education System}

To set the scene for discussions on micro-neoliberalism, this section reviews major education-sector 
changes in China and Shanghai under the neoliberal regime. China's shift to the market economy has brought new forms of entrepreneurial control in education and facilitated various overt and covert forms of privatization and commodification. Financing and administration of schools shifted from strong centralization with a narrow revenue base to a hierarchical system with considerable disparities reflecting diversified revenue (Ministry of Education [MoE] 2004a, 2004b; Tsang 1996). Local governments and schools gained more autonomy in operational decisions, but new forms of control were introduced to re-regulate schooling. As the neoliberal forces took hold, competition intensified between families, teachers, schools and governments. As in other parts of the world (Baker 2014), educational credentials replaced the government role under the planned economy in allocating individuals to labor force positions, in turn stratifying them into different social classes. Rapid expansion of formal education, partly driven by the neoliberal discourse, also led to credential inflation (Collins 2011).

Nationwide, expansion of higher education raised the gross enrollment rate from $3.5 \%$ in 1991 to 34.5\% in 2013 (MoE 2014). Linked to this, in 1991 only 28.7\% of high school graduates could enter higher education, but in 2013 87.6\% did so. In 1991, a degree from any university sufficed for an elite occupation, but by 2013 access was chiefly determined by degrees from high-status universities. When the previously narrow gate became wider, more families became able, and decided, to pursue university studies - i.e. neoliberal changes were the result not just of changing government policies but also of changing family policies. Degrees from some institutions lost status, which in turn intensified competition for degrees from prestigious universities. The Grade 12 University Entrance Examination (Gaokao) was the principal gate for entry, and became increasingly competitive. In turn, pressures intensified at lower levels: lower secondary students competed for admission to key upper secondary schools through the Grade 9 examination, Zhongkao; primary students competed for admission to high-performing lower secondary schools, and kindergarten children competed for high-performing primary schools. With echoes of the diploma disease identified by Dore (1976), families found themselves increasingly embarking on acquisition of credentials rather than genuine education, and private tutoring was factored into the strategic planning of families who could afford it (Yu \& Ding 2011).

In these circumstances students' examination performance, especially at the transition points, became the most important target and performance indicator for many local education bureaus, schools and teachers. Competition intensified among schools and teachers to recruit high performers, and drove some of them to tolerate or even encourage tutoring. Stress on performance indicators also heightened families' expectations of schools and teachers as providers of educational services. Changes in the education system also altered teachers' identities along the lines identified elsewhere by Ball (2015) from consciousness-driven educators to standards-driven service providers or a mixture of both. In the larger society, traditional values were mixed with new values. Teachers were still respected, but knowledge became quantified by performance indicators and goal attainments, and for teachers themselves by salaries and academic titles. Teaching remained a stable job, but was more vulnerable under the surveillance of various stakeholders. Further, the material privilege of the teaching profession was offset by increased availability of more lucrative jobs in the market economy. Since in addition urban teachers faced growing financial pressures, many decided to generate extra incomes through shadow education (W. Zhang 2014). 
Beyond the public system, the state has encouraged establishment of private (minban) schools run by entrepreneurs and community associations (Lin 1999; MoE 2015a). Throughout China, these schools have been empowered by the government with relatively modest regulation (Ding 2011). Private tutoring centers were widely seen as an extension of the same phenomenon; and in a further extension, the notion that teachers might receive extra incomes from supplementary tutoring became more acceptable as "fair trade". Related to these patterns was the transformation of parents and students into consumers: a child's academic success much depended on how families strategically screened and utilized the expanding and diversifying choices in the mainstream and the shadow, and how they negotiated and mobilized economic, social and informational resources (e.g. see Wu 2014; W. Zhang 2014).

\section{Shanghai's Equalization Policy in Theory and Practice}

The elite key schools in Shanghai, as in the whole country (Lin 1999; Tsang 2003; Wu 2014), were originally designed to promote excellence and act as examples for wider improvement. The schools received favorable government funding, had enviable facilities, and recruited the best teachers and students. According to Ding (2011), before the 1990s primary and secondary schools in Shanghai were all public and the hierarchy was based on the key school system and stratification of districts. The top-tier schools were at the municipal level, followed by key schools at the district level. At the lower end were ordinary schools of stratified quality (p.75). A 1997 report demonstrated sharp disparities in test scores between key and ordinary schools, and between Shanghai's urban and rural areas at both primary and lower secondary levels (Xie \& Tan 1997, 91-100). The neoliberal environment brought diversification of models. Some key schools remained fully-government institutions, some became private, and others became mixed. Yet despite this diversification and the possibility of opening new private schools, the number of elite institutions remained limited. By contrast, as household incomes increased and more families became aware of the benefits from attending the elite institutions, competition increased. Advantaged families used their economic and social capital (Wu 2014), and this bottom-up movement created a marketplace for school choice that in effect dispossessed lower class families.

These developments to some extent undermined other government measures to reduce inequalities. Since 1997 the government has required primary and lower secondary schools to recruit students (including migrant children) without entrance examinations from the neighborhoods in which the schools were located ( $\mathrm{Li} \mathrm{2007;} \mathrm{SEC} \mathrm{2015a;} \mathrm{MoE} \mathrm{2015b);} \mathrm{and} \mathrm{in} \mathrm{an} \mathrm{accompanying} \mathrm{measure} \mathrm{the}$ government prohibited schools from ranking of students and allocating the best performers to key classes. However, some schools ignored the requirements, merely changing the labels for high performing classes into "experimental classes” or “innovation classes”.

The government of course recognized that requirement for the schools to recruit from their neighbourhoods would only work well if disparities could also be reduced between neighbourhoods. In an effort to promote leadership from what were still informally called key schools, and to spread quality, the authorities encouraged the establishment of 'educational groups' in which key schools 
were made responsible for the academic performance of supervised schools (SEC 2015b). In addition, the government established more schools affiliated to key schools, mobilizing the reputations and resources of key schools through public-private partnerships. Figure 1 shows an example of possible association of primary and secondary schools in circles around a key upper secondary school. The illustration is simplified since most circles would have more schools and also tutoring enterprises. Further, the circles around School A are likely to be more numerous than is shown in Figure 1, and each school in the orbit of School A has its own circles that may overlap. Neoliberal changes have diversified forces and created new complexities. The policy has resulted in a new school hierarchy in which the former key schools and their feeder schools are at the top, followed by newly established affiliated schools. Schools supervised by these institutions are next, and ordinary schools in less developed districts remain at the bottom.

A further component of the equalization policy since 1997 was the ban on entrance examinations for lower secondary schools ( $\mathrm{Li} 2007$; MoE 2015b). The ban was linked to curriculum reforms aiming to promote whole-person development and to reduce the burden of excessive academic study. School hours were shortened, and homework reduced. However, key private schools and public schools that were formerly designated as key institutions enjoy more autonomy than other schools, including over what Ball, Maguire and Braun $(2012,40)$ called the 'freedom to decide which policy initiatives to get involved with and to what extent'. Moreover, in the neoliberal economy, shadow education expanded to fill the gap created by shorter hours and reduced homework. Thus, to a significant extent the contraction of the public sector stimulated expansion of the private sector - and students who could not afford the private charges were excluded from types of learning received by their peers.

Elaborating on differences between schools, the policies have in general been less strictly enforced in private than in public schools. Not only have private schools been permitted wider catchment areas, they can also determine their own curricula. Lower secondary schools have generally chosen to use this control over curriculum to focus strongly on the Grade 9 examination (Zhongkao). When teachers and parents interviewed for this study compared the study load in public and private schools, they all indicated that private schools assigned more homework and cut extracurricular activities and non-examination subjects to increase school hours for the examination subjects. Some schools may finish teaching the syllabus several months ahead of the standard schedule, and then allocate time to intensive preparation for the Grade 9 examination. Interviewees added that in the public sector the key schools were the most examination-oriented in part because of longstanding school cultures and in part because they had greater power to resist the stipulated distribution of teaching hours. For example, a physics teacher in a second-tier public key lower secondary school remarked:

Yes, [key] private schools enjoy more freedom. They enroll students ahead of the stipulated time of admission. Why do they perform well in Zhongkao? Their students learn the official curriculum in advance. Their future will be better than public schools, but only because they have good students rather than good education.

Another key private lower secondary school teacher, who used to work in a key public school, responded similarly:

Teacher: Key private schools are no doubt better than key public schools. In public schools they may only have one key class with high-performing students. But in key private schools, every class is equivalent to their key class... 
Researcher: Are key private schools good because of their student intake?

Teacher: $\quad$ I think it is the main reason.

Researcher: Do they have good student intake because they are not constrained by the nearby allocation policy?

Teacher: Right, right. They have the autonomy to select, one out of 10, from a larger pool of students. I do not think public schools have such power.

The examination orientation of key private as well as top public schools was also mentioned by other interviewed students and teachers. They frequently mentioned drilling of exercises and past examination papers. One public primary school teacher remarked that a specifically-named top private lower secondary school:

is non-stop drilling, and pushes students to compete for prizes in international competitions... My colleague's child is in this school... Private schools over-emphasize test and examination scores, and the level of government intervention is low.

Since key private lower secondary schools performed well in the Zhongkao in terms of student transition rates to key upper secondary schools, they became the most desired target for many families exerting school choice.

To sum up, as a result of government efforts to equalize the mainstream system, a new hierarchy emerged under the neoliberal forces. At the top are key private and public schools, next are schools related to these institutions, then come ordinary schools in developed districts, and finally come ordinary schools in less developed districts. Equalization policies have strengthened some of the weak schools and increased the number of schools in the second-top layer. However, the new stratification drives families with expectations and sufficient resources to find ways to access the desirable schools; and similarly it drives the schools to compete for high-performing students. Shadow education has assisted both the consumers and the providers in the process.

\section{The Scale and Nature of Shadow Education}

In seeking to reduce the study burden on students, the government has only been able to reduce school hours and homework since the shadow sector is mostly beyond the government reach. The authorities have issued commercial regulations for tutoring enterprises on such matters as contracts, safety and advertising; and the Shanghai Education Commission has regulations on school involvement in shadow education (SEC 2013b, 2015c). Schools and their personnel are prohibited from providing:

- tutoring or requiring students to receive tutoring;

- tutoring in collaboration with tutoring enterprises;

- buildings and facilities for tutoring; and

- student information to tutoring enterprises. 
At the same time, schools are encouraged to arrange free tutoring for students with learning difficulties before or after class and/or during holidays. However, these regulations are widely ignored, as evident in the data presented in this paper.

Beginning with the survey data on the scale of shadow education, $58.7 \%$ of the sampled students reported that they had received tutoring during the previous 12 months. Data are not available on trends, but the figures were consistent with other studies. For example, Y. Zhang $(2011,111)$ found in 2010 that $48.6 \%$ of sampled Grade 12 students in Jinan, Shandong Province, were receiving tutoring; and W. Zhang $(2014,443)$ found in 2011 that 45\% of sampled Grade 9 students in Chongqing were receiving tutoring.

Figure 2 shows the variation of reported tutoring participation in Shanghai across grades. Mathematics (81.5\% participation rate) and English (76.8\%) were the most popular subjects, partly because they were among core components for the assessments at the end of lower secondary and senior secondary schooling, and partly because competence in these subjects facilitated learning in other subjects. Families invested in tutoring in all grades, i.e. not just in those which were transition points; and demand was heightened not just by the examinations but also by peer pressure. Almost all the interviewed teachers referred to peer pressure among both parents and students, commonly describing it as blindly following the trend (genfeng). Technology intensified this pressure, including a popular electronic communication platform called WeChat that could be accessed on mobile phones and computers (China Daily 2015). With both voice and instant messaging functions, WeChat has facilitated communication among parents and teachers but has become a new source of anxiety. Parents in WeChat groups sought advice on tutoring and intensified each other's demand.

The questionnaire for the study on which this paper reports also asked about the venues of tutoring (Figure 3). One third of respondents indicated that they received tutoring at a teacher's home; one third on the premises of a company or social enterprise; $8.9 \%$ at the tutee's school; $17.2 \%$ at another school or mainstream educational institution, and $16.1 \%$ elsewhere. These statistics also provide a clue on the identity of the tutors, and in particular the strong role of teachers.

As shown in Table 1, tutoring in small groups/classes is most popular. Students and parents interviewed indicated that small classes usually have individualized services at lower cost than one-to-one tutoring. Small classes commonly accommodated 10-20 tutees, though in some cases stretched to 30, while large classes were similar in size to government classes with 30-40 tutees or in some cases over 50 .

Table 2 shows patterns of demand among different student groups. Slightly more female students received tutoring than males. The interviews suggested that this pattern might be explained by females' higher academic aspirations and greater conformity to parental desires. Compared to students who were local residents or from other countries/regions, tutoring participation of students with hukou in other provinces was low. This pattern can be understood in relation to the students' family background. Students whose parents had higher education degrees and greater incomes were more likely to receive tutoring, and families with only child invested more in tutoring. Students whose hukou was registered in other provinces included children of migrant workers with low socioeconomic status; and 69.8\% of 
students in this category had siblings compared to $29.7 \%$ for local students and students from other countries/regions. The above patterns provide evidence on inequalities in access to tutoring, which may in turn exacerbate disparities in schools.

\section{Four Mixing Zones}

When Kodakos and Kalavasis (2015) referred to "border management models”, they primarily had Greece in mind but addressed a concept of global relevance. This paper uses a different metaphor confluence - and notes that when sources of running water converge they form mixing zones. In the field of environmental science, the concept is especially applied to management of pollutants (e.g. Neely 1982; United States Environmental Protection Agency 2015). As noted above, shadow education can be viewed positively but can also be viewed negatively as if it is a pollutant. In any case, the shadow sector has its own stream that merges with the stream of regular schooling in the educational experiences of many children. Four types of mixing zones are identified here.

\section{Zone 1 - Kickbacks for Referral of Tutees}

The fact that some parents seek and value teachers' advice on tutoring is related to the first mixing zone, in which teachers generated incomes by tutee referral. Responding to the question from whom they obtained information on tutoring, just under one third of the 548 students who answered indicated that did so from teachers. Both parent and student interviewees indicated that they trusted teachers' recommendations. However, some teachers received kickbacks by referring students to their 'partner' providers of tutoring. The following dialogue with a key private school headteacher illustrates:

Researcher: We know some tutoring companies pay teachers for referrals of students.

Teacher: Indeed. I am disgusted with this. When educators and scholars are involved in cash business, what can they achieve and contribute? The teachers would say: I cannot provide tutoring myself, then let me earn kickbacks by promoting tutoring. They can earn huge amounts! A student pays 30,000 yuan [US\$4,500], and the teacher gets 1,000-2,000 yuan.

Researcher: A student pays 30,000 yuan?!

Teacher: In Grade 9, a monthly package costs 30,000 yuan; sometimes tutoring just for two weeks would cost that much. One mother just visited me to request leave for her child for the following two weeks. She wanted to send the child to a tutoring company instead of school, and had already spent over 50,000 yuan during the past two months....

I told her, if they really bring his learning and thinking abilities up to a higher level, then it may be worth the investment. But parents are blind. Based on what did she consider this company good? ... Of course, my standards of good teachers are high. But the company has no good teachers: are teachers who keep asking you to drill and exercise good? Many tutoring companies are like this: keep drilling the students, and seldom explain [teach].

Whatever the views of this headteacher, in this mixing zone the tutoring companies took advantage of the teachers' authority and relationships with students and parents - and the teachers did the same. 


\section{Zone 2 - Teachers as Tutors}

Perhaps a more problematic mixing zone arises when teachers themselves provide tutoring. Figure 4 provided numerical evidence on the blurring of geographic boundaries between mainstream and shadow education. Among the 548 students who gave usable responses, 35.8\% reported receipt of tutoring in teachers' homes, and $26.1 \%$ indicated doing so in mainstream schools. The reported hourly fees ranged from 100 to 500 yuan. Other teachers delivered their tutoring via companies. A mathematics teacher in a key public primary school reported that four colleagues provided tutoring, among whom one worked in a tutoring company and was paid 300 yuan for two hours in a class of 20. Another colleague earned 200 yuan per hour for one-to-one tutoring, and had still higher incomes when teaching the Olympiad mathematics syllabus.

The revenues from tutoring should of course be viewed in the context of teachers' salaries. Interviewees indicated that monthly salaries ranged from 3,000 yuan to 8,000 yuan according to the schools' financial circumstances and teachers' ranks. All principals interviewed expressed some sympathy for their teachers' involvement in tutoring in the context of what they described as moderate salaries. Salaries in Shanghai were higher than in the rest of China, but they were perceived to be low, especially by younger and non-local teachers. Many local colleagues had inherited housing from previous generations, but non-local ones were less likely to own accommodation. A teacher from a key private school spoke of colleague who used to provide lots of tutoring but who, after purchasing an apartment in another district, transferred to a public school in that district and almost stopped tutoring. A local teacher from an ordinary public school provided further useful comparisons:

My husband and I are both teachers. Our salaries are not high but my parents left us several properties. In our family including my parents-in-law, we have three apartments; and since my parents-in-law are still young and working we do not have financial burdens demanding us to generate extra incomes. By contrast, some young teachers in our school who came to Shanghai from elsewhere are under pressure. Then if they offer tutoring during weekends, and not to their own students, provided it does not negatively affect their school work it is totally fine to me.

This interviewee also noted pressures of supporting other family members. Most young teachers had no siblings because of the one-child policy, and were expected to support their parents. Married couples therefore commonly had to support four parents plus their own (single) children. Official salaries were far from sufficient to support the middle-class lifestyles that many perceived as appropriate in the consumer society. The interviewee who had been sympathetic to teachers providing tutoring nevertheless reported negatively on another case. This teacher and his wife owned several apartments and both had cars, but still ran tutoring classes in their home. They recruited their own students from their school, and charged for the tutoring. The interviewee stated:

This kind of teacher annoys me. Sometimes [in school] they do not teach the advanced questions tested in examination. If students want to learn, they have to attend their private lessons. They also force the lowest-performing students to go. One student is from a migrant family living in 10 square meters room without even a toilet! They assuaged their conscience by charging “only” 50 yuan per hour. I cannot imagine how they accept the money, and how they can do things like this! The migrant parents do not dare complain to the school because 
they are already discriminated against.

Yet while this practice offended the interviewee, the teachers providing the tutoring could have found it quite acceptable on the grounds that 1) many other teachers were involved in the tutoring market, which had modified teachers' traditional values; 2) they charged less than some other teachers; and 3) they were doing it for their wider family.

\section{Zone 3 - Tutoring-school Partnerships in Tutoring}

The third zone covers collaboration between tutoring companies and schools. At the primary level, tutoring for mathematics, English and Chinese competitions provides indicators for lower secondary schools who no longer have the guidance of the secondary schools entrance examination since tutoring for these competitions within schools is officially banned. Some schools then entrust tutoring enterprises to train and organize their students to attend the competitions. According to the tutoring practitioners interviewed, companies establish relationships with leaders of specific schools so that they send or recommend students to the companies. Shadow education is arguably the educational sector with the lowest level of government intervention, so tutoring practitioners largely ignored the ban on training for Olympiad and similar competitions.

Some elite key schools also organize such classes at school. To avoid overt conflict with official efforts to reduce the study burden, classes are disguised with labels such as 'training for thinking' or 'talent cultivation'. However, the content is closely related to mathematics Olympiad and similar competitions. These schools pay tutoring companies or high-performing teachers for the arrangements. The classes are free to students, but only high performers have access. The study found that some students received tutoring in order to pass the entrance test to a 'training for thinking' class.

\section{Zone 4 - Tutoring-school Partnerships in Admissions}

When the entrance examination for lower secondary schools was abolished, the admission arrangements for school-choice students went underground. In this hidden system, neither the criteria for admission nor the rights and obligations of participants are clearly stated. The underground admission processes in the market economy are then shaped by personal and business relationships between schools, tutoring providers and parents.

These developments show that what mattered most was not the examinations themselves but access within hierarchies. Parents seeking access had to become savvy consumers able to identify channels and plan strategically. According to the interviews, in order to choose a key lower secondary school through the underground admissions organized by the target school, the first need is for the student to have a strong Curriculum Vitae (CV), which was used to secure a ticket to the interviews organized by the school. Students with prizes and competitive certificates were most likely to get the tickets. Therefore, for these families the demand for tutoring was pushed to lower primary grades so as to collect as many as prizes and certificates as possible. One primary school teacher explained the system as follows:

Now that the admission methods are diversified, smart parents know how to build their children's CVs for the admission according to their children's strengths and weaknesses. But 
many parents are confused and do not know the ropes. Even though they try hard to improve their children's academic performance, that does not work.

The teacher added that he does not advise parents on school choice, because that domain is the parents' responsibility. Many parents then resort to companies which provide not only tutoring but also information on admissions to key schools. In order to obtain such information, the companies cultivate relationships with the high-performing schools.

The tutoring providers generate particularly high revenues from their relationships with schools for Grade 4 and Grade 5 tutorial classes. This may be the most controversial mixing zone at the confluence, because many teachers and school leaders are involved and the classes are institutional rather than individual practices. Target schools entrust tutoring companies and/or groups of in-service and retired teachers to establish the classes, track, train, assess, and select high-performing students for admission. The objective is to secure the best possible student intake. Students are tracked according to their examination grades in the supplementary classes, and are required to attend the classes each week throughout the academic year. The classes have taken over the responsibility for tracking, examination and ranking of a significant proportion of the student population, in place of the official examination.

The tutorial classes for Grades 4 and 5 also act as institutionalized relationships. Parents who feel that their children's CVs are not strong enough are given a 'choice' at the confluence through the tutorial classes which have strong relationships with their target schools. Families realize that if their children perform well in the classes and attract enough attention from the tutors, they can appear on the list of potential 'qualified' students recommended to the schools. In addition to scoring, the children are reminded to behave well and to respect the tutors.

\section{Conclusions}

This paper has focused on micro-neoliberalism in Shanghai at the institutional, family and individual levels. It adds to the wider literature on neoliberalism, showing forces at the confluence of mainstream and shadow education. Shanghai has distinctive features but also displays commonalities with the rest of China in its rapid improvement in wealth, intensified social competition, and emphasis on relationships. And as in many other parts of the world (Ball 2006, 143-146), Shanghai's education system has been increasingly influenced by marketization, managerialism and performativity. The market has created spaces for the flow of human and financial resources at the institutional level, and networks of relationships disseminate information and shape reputations of schools and tutoring centers. Managerialism and performativity have shaped ways in which schools, families and individuals have made meaning of and responded to policies that have sometimes conflicted. The mixing zones show that policies can be resisted, ignored and/or mediated by the various actors; and at the individual level, parents, students and tutoring providers are decision-makers alongside teachers and school leaders.

Figure 1 showed relationships between schools, which despite equalization policies remained hierarchical. Neoliberal policies have blurred the boundaries of private and public in the mainstream, and boundaries have been further blurred by the shadow sector. Figure 4 elaborates on Figure 1 by adding tutoring centers that have relationships with particular schools. It could be elaborated further by 
showing the private tutoring activities of teachers and school leaders from particular schools.

In the field of environmental science, mixing zones are identified not merely for descriptive purposes but also for management of pollutants (Bárcena Gómez 2015; United States Environmental Protection Agency 2015). For example, engineers can arrange the angles and speeds at which polluting effluents are discharged into relatively clean rivers so that the pollutants are dispersed effectively. Shadow education, it must be repeated, has positive as well as negative sides; but insofar as some dimensions may be viewed negatively as pollutants, questions arise about the policy implications for management of these components. To answer these questions, it is again useful to look at micro as well as macro levels. Concerning the latter, policies may be devised by central, municipal and district governments; but perhaps equally important are policies at the level of institutions.

The starting point for such policy-making should of course be with the objectives. The Shanghai authorities seem less concerned about some of the potential dimensions of backwash identified earlier than with others. Thus, they have not highlighted the potential for curriculum clash when students learn different content in the shadow sector and in their schooling; nor have they emphasized the dangers of pre-teaching in the shadow leading to boredom in the mainstream, or of students respecting their tutors more than their teachers. By contrast, the authorities have been actively concerned about the study burden on students and about dimensions of corruption. Concerning the latter, especially problematic are situations in which teachers tutor their own students after regular hours in exchange for fees. Also problematic are mutual referrals between teachers, and kickbacks when teachers refer students to companies. And at an institutional level, the authorities may be concerned about relationships between schools and tutoring companies that are potentially corrupting.

With these factors in mind, the authorities can devise macro-level regulations, guidelines and codes of conduct. However, micro-level actions are needed to implement - or even to operate in the absence of - macro-level instruments. Thus schools can set their own policies on whether teachers are permitted to tutor their own (or any) students; and since individuals are known at the school level, such policies are likely to have much greater sanction than statements made by distant governments. Similar remarks may apply to relationships between schools and tutoring companies. Western literature tends to emphasize the concepts of autonomy and accountability, sometimes placing them as contrasts to each other. Personnel in the Shanghai government have preferred instead to emphasize responsibility (SEC 2011). More perhaps needs to be achieved in the actualization of this approach, but it nevertheless points to a way to manage the confluence of mainstream and shadow at a micro level.

Responsibility can of course be combined with transparency, and in particular the authorities can encourage the sorts of issues discussed in this paper to be brought more fully into the public arena. Greater public discussion may also help tackle the less desirable aspects of family decision-making. Teachers sometimes report that they are pressed by parents to provide private lessons. Greater public awareness of the damaging implications can be a tool to dissuade parents from such actions. Similar remarks may apply to the ways in which elite schools partner with tutoring centers for classes in Grades 4 and 5 that in effect become the substitute for the entrance examination to lower secondary school. It would be naïve to think that all negative dimensions can be eradicated; but public exposure and discussion can at least be a check - and such activities at the micro level can help inform the meso 
and macro levels.

Finally, this paper has pertinence far beyond the confines of Shanghai and China. Some dimensions of the patterns described here are specific to these locations, including the speed at which incomes have risen, the pressures brought by the policy of one-child families, and some cultural approaches relating to respect for teachers and interpersonal relationships. However, the paper has shown that shadow education is a major phenomenon in many parts of the world and is growing globally. The precise nature of tutoring arrangements and the roles of institutions, teachers and families may vary, but many of the underlying forces are the same. As such, interactions at the confluence of mainstream and shadow education deserve much more attention internationally than they have received to date.

Acknowledgments: Financial support for the research reported in this paper was provided by the Small Project Fund of the University of Hong Kong and by General Research Fund (GRF) of the Hong Kong Research Grants Council (RGC) project number 17902815. The authors also express appreciation to the respondents in the schools and to the Shanghai Academy of Educational Sciences (SAES).

\section{References}

Apple, Michael W. 2006. Educating the "Right" Way: Markets, Standards, God, and Inequality. $2^{\text {nd }}$ ed. New York: Routledge.

Aurini, Janice, Scott Davies and Julian Dierkes (eds.) 2013. Out of the Shadows: The Global Intensification of Supplementary Education. Bingley: Emerald.

Baker, David P. 2014. The Schooled Society: The Educational Transformation of Global Culture. Stanford: Stanford University Press.

Ball, Stephen J. 2006. Education Policy and Social Class: The Selected Works of Stephen J. Ball. Abingdon: Routledge.

Ball, Stephen J. 2015. “Subjectivity as a Site of Struggle: Refusing Neoliberalism?” British Journal of Sociology of Education (Published online: 16 June) DOI:10.1080/01425692.2015.1044072

Ball, Stephen J., Meg Maguire and Annette Braun. 2012. How Schools do Policy: Policy Enactments in Secondary Schools. London: Routledge.

Bárcena Gómez, Javier Francisco. 2015. “Desarrollo de una metodología para delimitar zonas de mezcla de vertidos industriales en estuarios” ["Development of a Methodology to Allocate Mixing Zones of Industrial Discharges in Estuaries”]. Doctoral thesis, Universidad de Catabria.

Bernard, H. Russell and Gery W. Ryan. 2010. Analyzing Qualitative Data: Systematic Approaches. Thousand Oaks: SAGE.

Bray, Mark. 1999. The Shadow Education System: Private Tutoring and its Implications for Planners. Paris: UNESCO International Institute for Educational Planning (IIEP).

Bray, Mark. 2009. Confronting the Shadow Education System: What Government Policies for What Private Tutoring?. Paris: UNESCO International Institute for Educational Planning (IIEP). 
Bray, Mark. 2013. "Benefits and Tensions of Shadow Education: Comparative Perspectives on the Roles and Impact of Private Supplementary Tutoring in the Lives of Hong Kong Students.” Journal of International and Comparative Education 2 (1): 18-30.

Bray, Mark, Magda Nutsa Kobakhidze, Junyan Liu and Wei Zhang. 2016. “The Internal Dynamics of Privatised Public Education: Fee-charging Supplementary Tutoring Provided by Teachers in Cambodia.” International Journal of Educational Development 49, 291-299.

Bray, Mark and Chad Lykins. 2012. Shadow Education: Private Supplementary Tutoring and Its Implications for Policy Makers in Asia. Mandaluyong City: Asian Development Bank, and Hong Kong: Comparative Education Research Centre, The University of Hong Kong.

Cheng, Kai-Ming. 2010. "Shanghai and Hong Kong: Two Distinct Examples of Education Reform in China.” In OECD, Strong Performers and Successful Reformers in Education: Lessons from PISA for the United States, 83-115. Paris: Organisation for Economic Co-operation and Development.

China, People's Republic of. 2010. Outline of China's National Plan for Medium and Long-Term Education Reform and Development (2010-2020). Beijing: People’s Publishing House. [in Chinese]

China Daily 2015. “Wechat Becomes Major Platform for Chinese People.” 29 June. http://www.chinadaily.com.cn/china/2015-06/29/content 21129418.htm

Choi, Jaesung and Rosa Minhyo Cho. 2015. "Evaluating the Effects of Governmental Regulations on South Korean Private Cram Schools.” Asia Pacific Journal of Education in press. DOI 10.1080/02188791.2015.1064356

Coase, Ronald H. and Ning Wang. 2012. How China Became Capitalist. New York: Palgrave Macmillan.

Collins, Randall. 2011. “Credential Inflation and the Future of Universities.” Italian Journal of Sociology of Education 3 (2): 228-251.

Creswell, John W. 2012. Educational Research: Planning, Conducting, and Evaluating Quantitative and Qualitative Research $4^{\text {th }}$ ed. Boston: Pearson.

Ding, Xiaojiong. 2011. Policy Metamorphosis in China: A Case Study of Minban Education in Shanghai. Lanham: Lexington Books.

Dore, Ronald. 1976. The Diploma Disease: Education, Qualification and Development. Berkeley: University of California Press.

Fergany, Nader. 1994. Survey of Access to Primary Education and Acquisition of Basic Literacy Skills in Three Governorates in Egypt. Cairo: UNICEF and Almishkat Centre for Research and Training.

Gibbs, Graham R. (2007). Analyzing Qualitative Data. London: SAGE.

Guo, Shibao and Yan Guo (eds.) 2016. Spotlight on China: Changes in Education under China's Market Economy. Rotterdam: Sense.

Guo, Shibao, Yan Guo, Gulbahar Beckett, Qing Li and Linyuan Guo. 2013. "Changes in Chinese Education under Globalisation and Market Economy: Emerging Issues and Debates.” Compare: A Journal of Comparative and International Education 43 (2): 244-264.

Hartmann, Sarah. 2013. “Education ‘Home Delivery’ in Egypt: Private Tutoring and Social Stratification.” In Private Tutoring across the Mediterranean: Power Dynamics and Implications for Learning and Equity, 
edited by Mark Bray, André E. Mazawi and Ronald G. Sultana, 57-75, Rotterdam: Sense.

Japan, Ministry of Education, Culture, Sports, Science \& Technology. 2015. Survey on Expenditure on Children's Learning. Tokyo: Monbukagakusho Hokokusho. [in Japanese] http://www.mext.go.jp/b menu/toukei/chousa03/gakushuuhi/1268091.htm

Jo, Seong Hun. 2013. “The Track of Policies for Educational Equality and its Implications in Korea.” Journal of Educational Change 14 (1): 73-94.

Johnson, Burke and Larry Christensen. 2012. Educational Research: Quantitative, Qualitative, and Mixed Approaches. Los Angeles: SAGE.

Jokić, Boris (ed.) 2013. Emerging from the Shadow: A Comparative Qualitative Exploration of Private Tutoring in Eurasia. Zagreb: Network of Education Policy Centers.

Kassotakis, Michael and Athanasios Verdis. 2013. "Shadow Education in Greece: Characteristics, Consequences and Eradication Efforts.” In Private Tutoring across the Mediterranean: Power Dynamics and Implications for Learning and Equity, edited by Mark Bray, André E. Mazawi and Ronald G. Sultana, 93-113, Rotterdam: Sense.

Kobakhidze, Magda Nutsa 2014. “Corruption Risks of Private Tutoring: Case of Georgia.” Asia Pacific Journal of Education 34 (4), 455-475.

Kodakos, Anastassios and Fragiskos Kalavasis (eds.). 2015. Shadow Education System: Border Management Models of the School with the Structures of the Education Market. Rhodes: University of the Aegean.

Koo, Anita. 2016. "Expansion of Vocational Education in Neoliberal China: Hope and Despair among Rural Youth.” Journal of Education Policy 31 (1): 46-59.

Korean Statistical Information Service. 2015. 'Private Education Participation Rate by School Level'. http://kosis.kr/eng/statisticsList/statisticsList_01List.jsp?vwcd=MT_ETITLE\&parentId=C\#SubCont

Li, Jun. 2007. “Analysis on the Nearby Enrollment Policy of the Compulsory Education in China.” Doctoral dissertation, East China Normal University, Shanghai.

Lin, Jing. 1999. Social Transformation and Private Education in China. Westport: Praeger.

Liu, Junyan. 2015. "How a Research Instrument Changed in Different Settings: Methodological Lessons from Adaptation and Adjustment.” In Researching Private Supplementary Tutoring: Methodological Lessons from Diverse Cultures, edited by Mark Bray, Ora Kwo and Boris Jokić, 247-259, Dordrecht: Springer and Hong Kong: Comparative Education Research Centre, The University of Hong Kong.

Lipman, Pauline. 2011. The New Political Economy of Urban Education: Neoliberalism, Race, and the Right to the City. London: Routledge.

Manzon, Maria and Shaljan Areepattamannil 2014. "Shadow Education: Mapping the Global Discourse.” Asia Pacific Journal of Education 34 (4): 389-402.

Ministry of Education (MoE) 2004a. Basic Facts about the Development of Chinese Education. Beijing. [in Chinese] http://www.moe.edu.cn/publicfiles/business/htmlfiles/moe/moe 163/200408/2692.html

Ministry of Education (MoE) 2004b. Basic Facts about Chinese Higher Education. Beijing. [in Chinese] http://www.moe.edu.cn/publicfiles/business/htmlfiles/moe/moe_163/200408/2909.html 
Ministry of Education (MoE) 2014. Educational Statistics in 2013. Beijing. [in Chinese] http://www.moe.edu.cn/publicfiles/business/htmlfiles/moe/s8493/index.html

Ministry of Education (MoE) 2015a. Minban Education. Beijing. [in Chinese] http://www.moe.edu.cn/jyb sjzl/moe 364/moe 902/moe 985/tnull 10056.html

Ministry of Education (MoE) 2015b. Policy Analysis by the Counsel of Shanghai Education Commission, Yin Houqing. Beijing. [in Chinese] http://old.moe.gov.cn/publicfiles/business/htmlfiles/moe/s8659/201504/185491.html

National Bureau of Statistics of China. 2014. China Statistical Yearbook - 2014. Beijing: China Statistics Press.

Neely, W. Brock. 1982. “The Definition and Use of Mixing Zones.” Environmental Science and. Technology 16 (9): 518A-521A

Olssen, Mark and Michael Peters. 2005. "Neoliberalism, Higher Education and the Knowledge Economy: From the Free Market to Knowledge Capitalism.” Journal of Education Policy 20 (3): 313-345.

Patton, Michael Q. 2002. Qualitative Research and Evaluation Methods. Thousand Oaks: SAGE.

Peck, Jamie and Adam Tickell. 2002. “Neoliberalizing Space.” Antipode 34 (3): 380-404.

Peck, Jamie, Nik Theodore and Neil Brenner. 2009. "Neoliberal Urbanism: Models, Moments, Mutations.” SAIS Review 29 (1): 49-66.

Sato, Yuji (ed.) 2012. 100 Years of Juku and 50 Years of Juku Associations. Tokyo: Private Tutoring Federation. [in Japanese]

SEC (Shanghai Education Commission) 2011. Opinions about Further Improving the Principal Responsibility System in Primary and Secondary Schools. [in Chinese] http://wenku.baidu.com/view/90fc221ba76e58fafab0030c.html?from=search

SEC (Shanghai Education Commission) 2012. Basic Facts of Education in Shanghai. [in Chinese] http://www.shmec.gov.cn/web/concept/show article.php?article id=363

SEC (Shanghai Education Commission) 2013a. List of Demonstration High Schools in Shanghai. [in Chinese] http://www.shmec.gov.cn/web/glxx/listInfo.php?id=24819

SEC (Shanghai Education Commission) 2013b. Guidelines for Monitoring Minban (Private) Tutoring Institutions. [in Chinese] http://www.shmec.gov.cn/html/xxgk/201306/423042013001.php

SEC (Shanghai Education Commission) 2015a. Regulations on Admission at the Level of Compulsory Education. [in Chinese] http://www.shmec.gov.cn/html/xxgk/201502/420022015001.php

SEC (Shanghai Education Commission) 2015b. Guidelines on Balanced Development of Education and Promotion of Educational Groups. [in Chinese] http://www.shmec.gov.cn/html/xxgk/201511/402152015023.php

SEC (Shanghai Education Commission) 2015c. Rules Prohibiting Primary and Secondary Schools and In-service Teachers from Providing Tutoring. [in Chinese] http://www.shmec.gov.cn/web/xwzx/show_article.php?article_id=85374

Sellar, Sam and Bob Lingard. 2013. "Looking East: Shanghai, PISA 2009 and the Reconstitution of Reference Societies in the Global Education Policy Field.” Comparative Education 49 (4): 464-485. 
Seth, Michael J. 2002. Education Fever: Society, Politics, and the Pursuit of Schooling in South Korea. Honolulu: University of Hawai'i Press.

Shanghai Municipal People’s Government. 2015. The History of Shanghai. [in Chinese] http://www.shanghai.gov.cn/nw2/nw2314/nw3766/nw3767/nw3771/u1aw4.html

Shen, Hua. 2008. “An Investigation on Factors Influencing Private Supplementary Tutoring at the Level of Basic Education.” Economics of Education Research 6 (3): 1-10. [in Chinese]

SMBS (Shanghai Municipal Bureau of Statistics) 2014. Shanghai Statistical Yearbook 2014. Shanghai: China Statistics Press. [in Chinese]

Spradley, James P. 1979. The Ethnographic Interview. New York: Holt, Rinehart and Winston.

Sutton Trust. 2015. "London Pupils are Twice as Likely to Receive Private Tuition as Those outside the Capital.” The Sutton Trust, September 4.

http://www.suttontrust.com/newsarchive/london-pupils-are-twice-as-likely-to-receive-private-tuition-as-t hose-outside-the-capital/

Tan, Charlene. 2013. Learning from Shanghai: Lessons on Achieving Educational Success. Dordrecht: Springer.

Tan, Jason. 2009. "Private Tutoring in Singapore: Bursting out of the Shadows.” Journal of Youth Studies (Hong Kong) 12 (1), 93-103.

Tsang, Mun C. 1996. "Financial Reform of Basic Education in China.” Economics of Education Review 15 (4), 423-444.

Tsang, Mun C. 2003. “School Choice in the People’s Republic of China.” In Choosing Choice: School Choice in International Perspective, edited by David N. Plank and Gary Sykes, 164-195. New York: Teachers College Press.

United States Environmental Protection Agency. 2015. Basic Information about Mixing Zones. http://www.epa.gov/wqs-tech/basic-information-about-mixing-zones

Ward, Stephen. 2013. “Education Policy and the Marketization of Education”. In A Student's Guide to Education Studies, edited by Stephen Ward, 3-11. New York: Routledge.

Wu, Jinglian. 1999. Economic Reform in Contemporary China: Strategies and Practices. Shanghai: Shanghai Far-East Press. [in Chinese]

Wu, Xiaoxin. 2014. School Choice in China: A Different Tale?. New York: Routledge.

Xie, Anbang and Songhua Tan. 1997. National Report on the Quality of Compulsory Education. Shanghai: East China Normal University Press. [in Chinese]

Yu, Hongxia and Xiaohao Ding. 2011. "How to Get out of the Prisoner's Dilemma: Educational Resource Allocation and Private Tutoring.” Frontiers of Education in China 6 (2): 279-292.

Zeng, Kangmin. 1999. Dragon Gate: Competitive Examinations and their Consequences. London: Cassell.

Zhang, Minxuan. 2014. Lecture Entitled 'Performance and Reflections: Shanghai's Result in PISA and the Development of China’s Basic Education’. 8 April, East China Normal University, Shanghai. 
Zhang, Minxuan and Lingshuai Kong. 2012. "An Exploration of Reasons for Shanghai's Success in the OECD Program for International Student Assessment (PISA) 2009.” Frontiers of Education in China, 7 (1): 124-162.

Zhang, Minxuan, Jin Lu, Shengli Zhan, Xiaohu Zhu and Tingting Wang. 2011. "PISA in a Professional Perspective.” Educational Research 6: 3-10. [in Chinese]

Zhang, Wei. 2014. "The Demand for Shadow Education in China: Mainstream Teachers and Power Relations.” Asia Pacific Journal of Education 34 (4): 436-454.

Zhang, Wei and Mark Bray. 2015. "Shadow Education in Chongqing, China: Determinants of Demand and Policy Implications.” KEDI Journal of Educational Policy 12 (1): 83-106.

Zhang, Wei and Mark Bray. 2016. "Shadow Education: The Rise and Implications of Private Supplementary Tutoring.” In Spotlight on China: Changes in Education under China's Market Economy, edited by Shibao Guo and Yan Guo, 85-99. Rotterdam: Sense.

Zhang, Yu. 2011. “The Determinants of National College Entrance Exam Performance in China - With an Analysis of Private Tutoring.” Doctoral Dissertation, Columbia University, New York. 